\title{
THE SOCIOLINGUISTICS STUDY ON THE USE OF CODE MIXING IN GITA SAVITRI DEVI'S YOUTUBE CHANNEL VIDEO
}

\author{
Zul Astri ${ }^{1}$, Al Fian ${ }^{2}$ \\ 1) 2) Universitas Muslim Maros \\ 1)zulastri17@gmail.com \\ 2) alfian9818@gmail.com
}

\begin{abstract}
Sociolinguistics is a linguistic branch that studies the relationship between language and society. In this entire world, every people have their personal language style when they have interacted with other people. With the language variation that people have, they are able to mix some languages on their single utterance. When one language is mixed with the other language, in the sociolinguistics study it is called code-mixing. By applying code-mixing in social life, it has been widely used by a lot of people over the world. One Indonesian YouTuber named Gita Savitri Devi does code-mixing in some of her videos. Therefore, this research focused on code-mixing appears in Gita Savitri Devis's YouTube channel video. This research aimed to find out the types of code-mixing that emerge in Gita Savitri Devi's YouTube video. This research used a descriptive qualitative method and the writers are the main instrument. This research applied the documentation method in collecting the data. This research focused on analyzing the types of codemixing of Hoffman by applying content analysis. Furthermore, the result of the types was calculated by using Sudijono formula. In this study, the writers found that there were fifty-two data in types of code-mixing. The type of intra-sentential of code-mixing was the highest type and involving a change of pronunciation was the lowest one.
\end{abstract}

Keywords: Sociolinguistics, Code Mixing, Gita Savitri Devi, YouTube

\section{INTRODUCTION}

In the sociolinguistics phenomenon, which relates to language and society, sometimes many people can understand two or more languages. In the sociolinguistics field, it is known as bilingualism and multilingualism. Bilingualism is a person who can speak two languages and multilingualism is a person who can speak more languages (Sukrisna, 2019).

The two symptoms of language have become the speaking style in society. Moreover, code mixing is usually done by young people (Sukrisna, 2019). They usually conduct code-switching and code-mixing on their 
utterances. They think when they switch and mix the language they will look more prestigious. This symptom emerges on Indonesian YouTuber that is Gita Savitri Devi. In Gita's video, she often mixes her language on her utterances between Bahasa Indonesia and English. On her Youtube video, she also provides some motivations that can be beneficial to viewers of her videos. Moreover, her video promotes educational matters.

Some researchers have been conducted research about code-mixing. By conducting this research, the writers took several involved researchers that have been researched.

The first is Amsal (2011) who conduct research entitled "An Analysis of Code Mixing In Conversation of The Students at (SMPN) 3 XIII Koto Kampar". In his research, he aimed to look for the types of code-mixing of the student at SMPN 3 XIII Koto Kampar". He applied Muysken's theory (2000) to look for the types of code-mixing. The results showed that insertion was dominant within the student conversation, it is about $56.67 \%$ and it was classified into enough. The second researcher is Kurniati (2014) who conduct research entitled "A Sociolinguistics Analysis of Code Mixing on Nine Summer Ten Autumns Novel by Iwan Setiawan". In her research paper, she aimed to find out the types of code-mixing and the interferences that emerged within the novel. She analyzed twenty-two data from the novel. Based on the analyzed data, one of them is categorized as inner code-mixing., and nine of them are categorized as outer code-mixing, but she did not find interference within the novel. The last researcher is Berty (2015) who carried out research entitled "Code Mixing Used by Announcer of Venus Radio FM Makassar". In her thesis, the researcher found types of codemixing used by the announcer was sentential and lexical. The reasons of the announcer used code-mixing were because he/she was influenced by talking about a particular object, quoting someone else, stylish, and using familiar words. The functions of code-mixing were as topics and attitudes.

In this research, the writers looked for code-mixing on Gita Savitri Devi's video YouTube channel, especially for the types of code-mixing. The difference between this research and previous research is the writers looked for types of code-mixing which stated by Hoffman's theory.

In this research, the writer discussed about language study. A language is a tool of communication, if there is no language there is nothing to say. It is used by people in revealing ideas, thoughts, feelings to other people (Astri, 2017). Language is also a medium to establish and maintain relationships in social life. Therefore, humans and language cannot be separated from one another. In the linguistic field, sociolinguistics is a branch of language that explains the relationship between human and language itself.

Sociolinguistics is a branch of study that is focused on the relationship between 
language and society. Sociolinguistics derives from the words "social" and "linguist". The word "social" means of society and the word "linguist" means of language. Sociolinguistics divided into three characteristics such as characteristics of their function, characteristics of their speaker, and characteristics of language varieties. They constantly are able to interact and change one another in the speech community (Fishman in Sukrisna, 2019). Moreover, sociolinguistics is a branch of study related to human's everyday lives and how human uses language in their conversation (Wardaugh in Sukrisna, 2019).

From a sociolinguistics point of view, two things are studied namely, the connection of language and colonies between language uses and how the structures of society in which the language user life (Spolsky in Sukrisna, 2019). It is in line with Holmes (2013) who stated that sociolinguistics learn about relationships between languages and society. They are interested in debating for what reason people utilize various languages in various circumstances and they focus on distinguishing the social functions of language in delivering social meaning.

Based on the several definitions above related to sociolinguistics which stated by certain experts, it tends to be presumed that sociolinguistics is one linguistic branch that studies language related to community, function, variety, and users of the language.
Every community has a language character in communicating with one another.

\section{Code Mixing}

The symptom of doing code-mixing on daily communication is something common in society, especially in Indonesia. It becomes a normal communication by mixing language varieties while conducting communication. It is caused by some of the people in Indonesia who categorize as bilingualism or multilingualism. Saputro in Wulandari (2016) states that codemixing is an ability to apply more than a language in which the interlocutors or the writers mix two and more codes in a language discourse.

Moreover, Nababan in Yuliana (2015) argues that code-mixing is an ability to change a language from one language to another within the same utterance during the conversation or in a similar composed text or orally. It is in line with Jendra in Sumarsih (2014) who claims that code-mixing is a language phenomenon where the different language is mixing together within the same clause.

Based on several definitions related to code-mixing conveyed by some experts, it can be summarized that code-mixing is someone's ability to be able to mix languages within a conversation when interacting with each other, yet their conversation is still in the equal circumstance and only the language that they change. Moreover, according to Wulandari (2016), the background of education, social life, 
culture, economy, and the environment influences people in mixing the language.

\section{Types of Code Mixing}

According to Hoffman (1991), the types of code mixing divided as follow:

a. Intra-sentential code mixing

The meaning of intra-sentential code mixing occurs within a phrase, a clause, or in sentence form, as when an Indonesia-English bilingual person said:

$\mathrm{X}$ : "Hari ini saya ada middle test, mata pelajaran Mam Eni"

(Today I have a middle test, it is Mam Eni's Subject)

Y: “Hmm. Ya kamu mesti study hard agar kamu dapat memperoleh nilai yang tinggi"

(Hmm. You have to study hard in order you get a high score)

From the example of the above conversation between $X$ and $Y$, two of the speakers mix the language among Indonesian language and English.The speaker $X$ says "Besok saya akan menghadapi middle test, mata kuliah Mam Eni" and the speaker $\mathrm{Y}$ replies “Hmm. Ya kamu harus study hard agar kamu dapat nilai yang tinggi". Therefore, the mixing that they do in their conversation called Intra-sentential codemixing because they mix the language within sentence boundary. b. Intra-lexical code mixing Intra lexical code-mixing exists when the word is attached by the speakers within their spoken language, as when an Indonesia-English bilingual says:

Naila: "Fian, kamu sudah nge-follow Twitter saya belum (Fian, have you followed my Twitter account)

Fian: "Belum Naila, kamu juga belum menge-save WA Saya"

(Not yet Naila, You do not save my WA yet too)

From the conversation above, Naila and Fian do code-mixing in the form of intra lexical, because Naila adds the word "nge" before the word "follow" and Fian adds the word "menge" before the word "save". Therefore, it can be concluded that Naila and Fian mix two languages within word level and it called Intra lexical code-mixing.

c. Involving a change of pronunciation Involving a change of pronunciation exists when someone mixes the language in the level of phonological. For instance, when Indonesian speaks English, occasionally the word they produced in oral is modified to Indonesian structure of phonology.

Furthermore, Suwito in Sukrisna (2019) divides types of code-mixing into two namely: inner code-mixing and outer code-mixing. 
a. Inner code mixing

Inner code-mixing is a type of codemixing used by the speaker or the writer and they mix that language into the nature of the language that they have. Occasionally, it is conducted by Indonesian since Indonesia has a lot of traditional language in each region or place. Therefore, they mix their region language within Indonesian language by inserting word particle of their region or some varieties and language styles of dialect.

b. Outer code mixing

Outer code-mixing is a type of codemixing used by the speaker or writer and they mix that language into the foreign languages to their official language that they have. For instance, in using English as a foreign language, people attach English words to the official language.

In addition, Muysken (2000) divides types of code-mixing into three namely insertion, alternation, and congruent lexicalization. Here the distinction

\section{a. Insertion}

Insertion is a type $f$ code mixing where someone attaches a word on their spoken or written language. Generally, they applied this insertion since the speaker or the writer did not recognize well the meaning of the word on their national language. Therefore, they mix the words in insertion.
Example:

Farid: Nu, kamu akan shock kalau dengar cerita ini!

(Nu, you will shock if you heard this story)

Nunu: Kabar apa Farid? Hoax atau tidak?!

(What story is? Hoax or not)

Based on the conversation above, Farid and Nunu used Indonesian as dominant language, they insert English words within the conversation above. The insertion word that they used is "shock" and "hoax". Hence, the types of code mixing occurred in this type is insertion of code mixing.

\section{b. Alternation}

Alternation is a type of code mixing used by the speaker or writer and they mix the languages into a form of phrase.

Example:

Farid: Nu, kamu sudah menyelesaikan your assignment belum?

(Nu, have you finished your assignment?)

Nunu: Belum Farid, hari ini aku little bit sick. Jadi aku lupa

(Not yet Farid, today I feel little bit sick. So, I forgot it).

The conversation between Farid and Nunu is about the assignment. When the first speaker asks the second speaker by using the Indonesian language that she has finished her assignment or not, but 
the first speaker mixes the language that they used in English in the middle of his utterance when he was saying your assignment. Then, the second speaker replies to the first speaker's question, she said "Belum Farid, hari ini aku little bit sick. jadi aku lupa". Based on the second speaker's replied, she mixed the Indonesian language in the middle of her utterance, the phrase is " $a$ little bit sick. Therefore, it can be concluded that in alternation, two speakers mixed the language into a form of phrase.

\section{c. Congruent lexicalization}

Congruent lexicalization is a type of codemixing used by the speaker when the language is influenced by a dialect of the speaker. It means when someone produce a language, the English word produced by the speaker is similar to the foreign language. The official language of Indonesia has a few similar words to English. Here an example of the conversation related to congruent lexicalization:

Example:

Farid: Nu, kenapa kamu tidak mengangkat telephone saya?

(Nu, why you do not accept my telephone)

Nunu: Maaf, soalnya tadi saya lagi mengerjakan tugas di computer (Sorry, I was doing my task on my computer)
The conversation above showed that two speakers did congruent lexicalization since the words appear such telephone and computer identified as congruent lexicalization

In analyzing the Gita Savitri Devi's Youtube Channel video, the writers looked for the types of code-mixing based on the theory of Hoffman. Many of the sociolinguists clarified types of code-mixing, in this case, the writers proposed three experts, and Hoffman already reflected all the theory

\section{METHOD}

In this research, the writers conducted descriptive qualitative research since the writers collected the data, analyzed the data, and concluded the data that had been analyzed. Gunawan, (2013) states that qualitative research is a kind of research without statistical procedures or other forms of calculation.

The writers used purposive sampling in choosing the video. The chosen video contains knowledge about how to avoid hoaxes and hate speech.

The writers used the documentation method to collect the data and then analyzed the data by applying content analysis. Data collection was carried out by the author, then the authors analyzed the data to obtain research result.

According to Leedy \& Ormrod (2015), content analysis is an expounded and efficient assessment of the substance of explicit 
assemblage of texture to separate examples, subjects or inclinations. Content analysis is normally done on human correspondence structure. For example books, papers, individual diaries, official records, films, TV, art, music, and human interaction video. Along these lines, the writers employed content analysis in data analysis technique then the writers analyzed the video and after that read the written transcript that the writers had written

\section{FINDING AND DISCUSSION}

Data percentage based on types of code mixing.

Table 1. The Percentages of Types of Code Mixing in Gita's Video

\begin{tabular}{|c|l|c|}
\hline No & Types of Code Mixing & Percentages \\
\hline 1 & $\begin{array}{l}\text { Intra sentential of code } \\
\text { mixing }\end{array}$ & $88,46 \%$ \\
\hline 2 & $\begin{array}{l}\text { Intra lexical of code } \\
\text { mixing }\end{array}$ & 0 \\
\hline 3 & $\begin{array}{l}\text { Involving a change of } \\
\text { pronunciation }\end{array}$ & $11,54 \%$ \\
\hline \multicolumn{2}{|c|}{ Total } \\
\hline
\end{tabular}

Based on the data above, the writers concluded that the most of types of codemixing that appears in Gita's video are intra sentential and intra lexical of code-mixing. Meanwhile, involving a change of pronunciation has no data. Related to Hoffman's theory, tha data can be seen from the classification of the data below:

\section{Intra Sentential of Code Mixing}

This code mixing type occurred in word, phrase, and clause or sentence boundary in someone's utterance.

\section{a. Word}

1) Heeee finally, kalau gue nih yah, kalau misalnya ngomongin soal pemilu nih The utterance above appeared on Gita's video at 00:14 seconds. The language she used in their utterance was Indonesian language and Gita mixed the English word "finally" in her utterance. The word "finally" means "akhirnya" in Indonesian language. Gita did types of code-mixing in intra-sentential since she mixed her language in a word boundary.

\section{2) Terus semua orang itu bisa jadi jurnalis} padahal beritanya gak credible.

The sentence above appears in Gita's speeches at 00:43 seconds. In her utterance, she inserted the word "credible". Based on Hoffman's theory, Gita did intra sentential for this type of word.

Based on the data above, it was found that Gita Savitri did code-mixing by using two languages in one clause. This is in line with Jendra in Sumarsih (2014) which states that code-mixing is a language phenomenon in which different languages are mixed into one in the same clause.

\section{b. Phrase}

1) Nah, kalau urusan hate speech atau ujaran kebencian nih sebenernya rada ribet sih kalau menurut gue.

The utterance of Gita above appears at 02:45 minutes. She mixed her language from Indonesian to English. She 
said, "hate speech" in her utterance. The mixing that Gita said is classified into a phrase form. Therefore, the types of code-mixing that Gita made is intra sentential.

2) Karena ini tuh menyangkut kayak apa yah freedom of speech atau kebebasan berpendapat.

The code-mixing which appeared in Gita's utterance appeared at 02:52 minutes. She inserted the phrase "freedom of speech" in her Indonesian language. The code-mixing that Gita made is in the form of phrase and it is indicated as intrasentential of code-mixing in phrase boundary.

\section{c. Sentence}

1) Halo semuanya, kembali lagi di video gua. Let's talk about something veryvery important.

The mixing above appeared at 00:01 00:06 seconds. It can be seen from the data 44 that Gita attached the sentence "Let's talk about something very-very important" in her utterance. She mixed her official language with English. Therefore, in the types of code-mixing argued by Hoffman's theory, the codemixing types that Gita made were classified by intra-sentential in sentence form.

\section{2) Last but not least, I wanna thank Google} Indonesia and also Bawaslu for making this video possible dan gua pingin ngajak teman-teman semua yang nonton video gua untuk menyukseskan pemilu 2019.

The code mixing above emerged in Gita's video at 09:00-09:05 minutes. Gita inserted "Last but not least, I wanna thank Google Indonesia and also Bawaslu for making this video possible" in her utterance. She mixed her official language with English. Therefore, in the types of code mixing argued by Hoffman theory, code mixing types that Gita did was classified by intra-sentential of code mixing in sentence form.

The mixing of two languages by Savitri is in line with the theory expressed by Saputro in Wulandari (2016) which states that code-mixing is the ability to apply more than just a language where the interlocutor or writer mixes two or more codes in a language discourse.

\section{Intra Lexical of Code Mixing}

This type occurs as when someone attaches word boundary in their spoken language.

a. Prefix

1) Dan kita mau langsung buru- buru aja nge-share di sosial media kita.

Related to intra lexical type of codemixing in Gita's video. She attached he Indonesian affixation "nge" before the word "share". "Nge" as prefix and "share" as the original word, it became intra lexical of "Nge-share". In the Indonesian language, the word "nge- 
share" means "ngebagiin". Obviously, it does not standard language because the standard word of "nge-share" is "membagikan". The word "nge-share" is intra lexical of code-mixing and it came out on Gita's utterance at 01:59 minutes.

\section{b. Suffix}

1) Kalau misalnya kita lihat berita jangan cuma ngeliat headlinenya doang.

The data above shows that there is a suffix "nya" at the end of the word "headline". It happens when English word mixes with Indonesian affixation that suffix. The word "headline" as a word and "nya" as a suffix. It includes intra- lexical code-mixing (headlinenya).

\section{Involving a Change of Pronunciation}

In this video, the writers did not find data that showed as the types code mixing involving a change of pronunciation.

Berdasarkan data yang didapatkan di atas ditemukan beragam tipe code mixing yang di dapatkan dalam video Gita Savitri.

\section{CONCLUSION}

By analyzing the result of this research, the writers found some of the codes mixing on Gita Savitri Devi's YouTube channel video. The types of code-mixing were analyzed by applying the theory of Hoffman. The types of codemixing from this study were in the form of intra- sentential of code-mixing, intra- sentential, intra-lexical of code-mixing, and involving a change of pronunciation.

The result of the research, for the types of code-mixing, there were 52 data that the writers found. The data showed that intrasentencial of code-mixing was the highest types in Gita's video namely $88.46 \%$. Moreover, the author found only $11,54 \%$ for Intra-lexical of code-mixing. Furthermore, the writers did not find any data indicated as involving a change of pronunciation.

\section{BIBLIOGRAPHY}

Amsal. (2011). An Analysis of Code Mixing in Conversation of the Students at State Junior High School (SMPN) 3 XIII Koto Kampar. Pekanbaru: State Islamic University Sultan Kasim Riau.

Astri, Zul. 2017. The Typical Linguistic Feature of English Used by Indonesian Tourist Guide. Proceedings The 2nd Annual Seminar on English Language Studies, Makassar: 14 December 2017. Page.33-47

Berty, R. (2015). Code Mixing Used by Announcer of Venus Radio FM Makassar. Makassar: Faculty of Adab and Humanities, State Islamic University of Allauddin.

Djunaidi, M., G., \& Almanshur, F. (2009). Metodologi Penelitian Kualitatif. Yogyakarta.

Gunawan, I. (2013). Metode Penelitian Kualitatif Teori dan Praktek.(3rd Ed). PT Bumi Aksara.

Harwell, R., M. (2013). Research design: Qualitative, quantitative, and mixed methods. Retrived November 13, 2019 from 
http://www.cehd.umn.edu/edpsych/peo ple/Faculty/harwell.html.

Hoffman, C. (1991). An Introduction to Bilingualism. New York: Roudledge Tailor and Francis Group.

Holmes, J. (2013). An Introduction to Sociolinguistics 2nd Edition. London: Oxford University Press.

Kurniati, I. (2014). A Sociolinguistic Analysis of Code Mixing On Nine Summer Ten Autumns Novel By Iwan Setiawan. UIN Syarif Hidayatullah Jakarta.

Leedy, P. D., \& Ormrod, J. E. (2015). Practical Research Planning and Design (11th Ed). England: Pearson Education Limited.

Muysken, P. (2000). Bilingual Speech A Typology of Code Mixing. United Kingdom: Cambridge University Press.

Tanasy, N., Nasir, A. M., \& Yulianti, N. I. R. (2020). Mapping the Linguistic Politeness of Dusun Tangkuru Society: The Pattern of Politeness in Makassar. Elsya: Journal of English Language Studies, 2(3), 82-87.

Rasyid, R., Tanasy, N., \& Nasir, A. M. (2019). Testing the Effectiveness of "English Language" Course Book for Indonesian
Senior High School Students. Elsya: Journal of English Language Studies, 1(3), 102-109.

Sudijono, A. (2006). Pengantar Statistik Pendidikan. Jakarta: PT Raja Grafindo Persada.

Sukrisna, A. (2019). An Analysis Of Using Code Mixing On Atta Halilintar's Video Youtube Channel. Raden Intan State Islamic University Lampung.

Sumarsih. (2014). Code Switching and Code Mixing in Indonesia: Study in Sociolinguistics. English Language and Literature Studies, Volume 4, No 1, 2, p. 79.

Wulandari, S. (2016). Indonesian-English Code Mixing in Raditya Dika's Manusia Setengah Salmon. Journal on English as a Foreign Language, Volume 6, No 1, p. 7282

Yuliana, et al. (2015). Code Mixing And CodeSwitching of Indonesian Celebrities: A Comparative Study. Jurnal Lingua Cultura, p. 47-48. 